\title{
Economic Interdependence and War
}

\section{Citation}

Cooper, Richard N. 2014. Economic Interdependence and War. In The Next Great War? The Roots of World War I and the Risk of US-China Conflict, eds. Richard N. Rosecrance and Steven E. Miller. Cambridge: The MIT Press.

\section{Permanent link}

http://nrs.harvard.edu/urn-3:HUL.InstRepos:34903181

\section{Terms of Use}

This article was downloaded from Harvard University's DASH repository, and is made available under the terms and conditions applicable to Open Access Policy Articles, as set forth at http:// nrs.harvard.edu/urn-3:HUL.InstRepos:dash.current.terms-of-use\#OAP

\section{Share Your Story}

The Harvard community has made this article openly available.

Please share how this access benefits you. Submit a story.

\section{Accessibility}




\title{
Economic Interdependence and War
}

\author{
Richard N. Cooper \\ Harvard University
}

\section{Introduction}

The motivating question for this paper is whether a high degree of economic interdependence between countries reduces the probability of war between them, with the principal focus being on the First World War, which began a century ago. The issue achieves salience because the outbreak of the Great War (later renamed the First World War) followed four decades of rapidly growing economic interaction among the countries of western Europe and indeed between them and the far corners of the world. The period 1870-1913 has sometimes been called the first globalization, to be followed a hundred years later by a second great period of globalization. Actually, the first globalization was in the $16^{\text {th }}$ century, which involved the life-transforming transmission of plants and diseases around the world.

The fact that the First World War broke out in 1914 is frequently adduced as evidence that high economic interdependence does not ensure that war will not take place between the relevant countries - and so it was. Often cited in this connection is Norman Angell (1910), to the effect that the high economic interdependence and resulting common economic interests should make war inconceivable. Similar arguments are made today with respect to the modern world, and in particular the relationship between the United States and China. 
This paper will first document the growth in economic interdependence in the late $19^{\text {th }}$ century and again in the late $20^{\text {th }}$ century. It will report the main message Angell meant to convey to his readers, which has since been much misinterpreted. It will then offer an analysis of the outbreak of World War I consistent with what Angell actually said. It puts much more weight on the role of Russia, which plausibly thought it could gain economically from a European war. Finally, it offers a few concluding remarks on the present situation, with special attention to China, a rising power, and the United States, the dominant power.

\section{Growth of Economic Interdependence}

Technological developments followed by capital investment greatly reduced both the cost and the uncertainties associated with long-distance communication and transportation in the late $19^{\text {th }}$ century, most notably the telegraph and the use of steam power for locomotion both on land and at sea. The modern era can plausibly be dated from the 1860 s, which saw the laying of the first successful trans-Atlantic cable (1866), which meant for the first time a message could travel much faster than a person (and the diseases the messenger might carry). London had been linked to Paris in this way 15 years earlier. The trans-continental railway in the United States and the Suez Canal were both opened three years later, greatly easing transportation between Europe and Asia and between Asia and the populated east coast of the United States. The steamship greatly reduced travel times and their variability compared with sailing vessels, such that the travel time from Britain to New York was reduced from five to seven weeks in the 1830 s to a reliable two weeks in the 1870 s. These developments, and the soon thereafter invention of refrigeration, resulted in a veritable explosion of trade and in 
movements of financial capital, along with people and ideas. Also, many European countries, led by Britain, reduced their duties on imports.

Table 1 presents the ratio of merchandise exports to estimated gross domestic product (a measure of the total economic output of a country for a given year) for 1870, 1913, 1973, and 1998 for nine leading countries and for the world. It can be seen there that trade was more important for Britain, which was the world's leading trading nation, than for other countries already in 1870 . But this importance grew by nearly fifty percent by 1913 , to over 17 percent, and by proportionately even more for the other listed countries. Germany also showed a relatively heavy dependence on exports (as did most smaller European countries such as Belgium, the Netherlands, and Switzerland, not shown here). That dependence was notably less for France, and still less for Russia and the USA, both of which sported high protective tariffs against imports ( 84 percent on manufactures in 1913 in Russia, compared with 44 percent in the USA, 20 percent in France, and 0 percent in Britain) - which, according to wellestablished economic analysis, will over time also hurt exports (data from Bairoch, 1989, reported in Findlay and O'Rourke).

The period between 1913 and 1973 saw two world wars and the Great Depression of the 1930s, all of which discouraged trade - partly through disruption and lower incomes, partly through the sharp increase in trade-restrictive policies, which however began to be eased gradually starting in the late 1940s. The importance of exports to Britain actually fell between 1913 and 1973, as it did for China, India, and Spain, all of which had introduced strong traderestricting policies. But for the other listed countries, exports were more important 
economically even than they had been in 1913. And this relative importance greatly increased (except for India) by the end of the century, during the recent period of globalization.

Table 2 offers a different measure of interdependence: the importance (again relative to GDP) of ownership of assets abroad for five leading capital-exporting countries in 1914 and in 2005 (these are gross assets, not netted against liabilities to foreigners, which also grew substantially, since much British investment, for example, was in the United States, and the other way around). It can be seen that by 1914 the foreign assets of Britain - far the largest investor abroad - were already approaching GDP in magnitude. It was also significant for France, although much lower than for Britain, and still lower for Germany and the United States, the other largest economies. Much of this foreign investment was lost or sold during the world wars. But in the second half of the $20^{\text {th }}$ century foreign investment resumed on an even larger scale, and by 2005 reached more than twice GDP for Britain and nearly twice for France; not far short of GDP for Germany and the United States (which was the world's largest foreign investor in dollar value); and half GDP for Japan, in 2005 the world's second largest economy after the United States.

In addition to goods and financial capital, people began to move on a large scale in the late $19^{\text {th }}$ century, facilitated by the greater ease and lower cost of long-distance travel, mainly from Europe to North and South America, but also within the British empire, especially from India to many other British possessions, and from China. Gross annual emigration from Europe rose from under 300,000 before 1865 to 700,000 in the 1880 s to over 1.2 million in the first decade of the $20^{\text {th }}$ century (Chiswick and Hatton, p.69). 
And of course ideas - especially technology - were rapidly disseminated. The railroad and steam locomotives were first developed in Britain, but the invention was so attractive that it quickly spread to other parts of the world, often facilitated by British investments. British and other European and increasingly American machinery involved not only trade in goods, but introduced new techniques of production. So national economies were tied more closely together through many channels.

\section{Rehabilitating Norman Angell}

It was against this background that Norman Angell wrote The Great Illusion (1910). He was disturbed by the naval race that was taking place between Britain and Germany during the first decade of the century, especially the construction on both sides of huge Dreadnought-class battleships. Not only was this vastly expensive in budgetary terms, but Angell could not see how they could possibly be useful, since war or even the threat of war could not produce greater prosperity. The book's main message was not that a high degree of economic interdependence between these two large economies would make war between them inconceivable, but rather that it would make such a war stupid (my term, not Angell's). Concretely, even the "winner" in a war between them would end up being worse off after the victory than before. This was, in Angell's view, in sharp contrast with many previous wars, where the winner could plausibly expect to gain from a victorious war, in booty or in territory. Modern economies were built on money and credit, both requiring trust and benign conditions that would be destroyed or badly damaged by war under modern conditions. In this of course Angell was completely correct. Victorious Britain was worse off after the war, having inter alia depleted its overseas investments to pay for the war, not to mention having lost or maimed 
thousands of young men, as was France. It is noteworthy, however, that although many of Angell's arguments were couched in general terms, he was specifically addressing Britain and especially Germany (as Ferguson (1998) has well noted), not all countries or even all European countries.

Origin of the Great War

Why then did such a stupid war start? Here is not the place to recount in detail the actual sequence of events leading to the German invasion of Belgium on August 3, 1914, or the extensive imputation of motivations or the "domino" logic of the relationships among events. They have been gone over many times, and interpretations still differ a century later (see, e.g., Clark, Cowley, Ferguson, Langer, McMeekin, Taylor, Turner). Nonetheless, it is useful briefly to review the main events, since international tensions were occasionally high over previous decades, even resulting in limited wars, but then seemed to recede, as the conflicts were "managed" diplomatically. In general, compared with earlier periods in Europe, the $19^{\text {th }}$ century was one of peace after the defeat of Napoleon in 1815, managed by the "Concert of Europe." To be sure, there were several wars involving the major powers: the Crimean War of 1853-54, pitting Britain, France, and OttomanTurkey against Russia, the Austrian-Prussian War of 1866, the Franco-Prussian War of 1870-71, and the Russo-Turkish War of 1877-78. But they were all relatively brief, limited in their military engagements, and settled by negotiation. A German-Austrian alliance was formed for five years in 1879, renewed regularly until 1918, which newly-created Italy joined in 1882, forming the Triple Alliance. In partial response, a 
Franco-Russian alliance was formed in 1894. Britain maintained its distance from such formal alliances, although from time to time it was wooed by both groups. And joint British-French military planning started in 1904, creating French expectations of British support under some circumstances, without (as the British government reminded France from time to time) representing a formal commitment.

Britain was the established dominant power by 1900 , although that position was never definitively accepted by France, a resentful power still smarting from its defeat in 1871 and the loss of Alsace-Lorraine, and no doubt still remembering Napoleon's defeat nearly a century earlier. Germany was seen in Britain and France as a rising power posing some threat to each, although in economic terms the United States, safely on the western side of the Atlantic with a tradition of self-absorption, was by 1990 larger than any of the three western European economies. But from a German and Austrian perspective (and also some French, viewing the development more positively as a counter-weight to Germany) Russia was the rising power, seen as a potential threat to their interests in eastern and southeastern Europe and in the Near East. Italy, Japan, and the United States were aspiring powers, joining the scramble for overseas colonies late in the century. Spain and Portugal had passed their prime, the Ottoman Empire based in Istanbul was seen as the sick man of Europe and probably on its last legs, and the Austrian-Hungarian dual monarchy was also viewed as very fragile.

It is worth noting that there were far fewer centers of national policy-making in 1913 than now, roughly 50 as opposed to over 200 today. All of Africa except Ethiopia was under the effective, usually determining, influence of one or another European country, as was Asia except for Japan, China, Siam (Thailand), Persia, and Afghanistan - and even in those countries 
European influence, and rivalry, was strong. Most of the western hemisphere had separated from European control, although British influence remained strong in some places. Independent countries were concentrated in Europe and the western hemisphere.

There were many tense incidents among European countries in the decades before 1914, of which a short and very incomplete list would include the British-German naval race, already alluded to, in which Britain demonstrated its willingness to spend whatever was necessary to stay well ahead of Germany in warships; but also Fashoda (1898), the Boer War (1901-3), Morocco (1906 and again in 1911), the Austrian annexation of Bosnia-Herzegovina (1908) - which especially affronted Serbia - Tripoli (Libya,1911), and two Balkan wars (1912-13) involving Serbia, Bulgaria, Greece, Montenegro, and the Ottoman Empire. Each was brief and brought to an end by intercession of the great powers through a combination of threats and negotiation. These experiences created a climate of expectation that the "powers" could manage matters well enough to keep them from escalating out of control. But some of the powers were not so sure. Germany passed an army law in July 1913 to raise the size of its peacetime army by 136,000 to 890,000 men. France followed a month later with the controversial Three Year Law, which would extend the term of conscripts and raise the French army to 700,000. And in October Russia adopted its Great Program, to raise its winter peacetime army (i.e. outside the harvest season) by 800,000 men by 1917 (Clark, pp.330-32; McDonald, pp.209-12). 
July 1914

On June 28, 1914, the Archduke Ferdinand, nephew of Hapsburg Emperor Franz Josef and heir to his throne, was assassinated in Sarajevo by a Bosnian Serb, suspected (correctly as it turned out, but without hard evidence at the time) of being encouraged and supported by elements of the Serbian government. A strong debate started in Vienna about how to respond to this affront and provocation. Vienna received the infamous "blank check" from Berlin to deal with the affront as Vienna thought appropriate. Hungarian prime minister Tisza objected to the threat of war, urged by others and especially by chief of army staff Conrad, but eventually relented on condition that no Serbian territory be absorbed into Austria.

A summit meeting between France (president Poincare joined by newly installed prime minister and foreign minister Viviani) and Russia (Tsar Nicholas and his senior officials) took place on July 20-23, and Austria did not want to act until Poincare was on his way by warship back to France, to avoid Franco-Russian coordination of their responses. Germany had hoped for quick and decisive action by Austria, whatever it chose to do, but the resulting 48-hour ultimatum to Serbia with hard conditions was not made until July 23, (with Poincare and Viviani at sea) nearly four weeks after the assassination. Perhaps surprisingly, Serbia gave a generally responsive albeit ambiguous reply, clearly rejecting only one of the conditions. But Austria wanted to punish Serbia once and for all for its impudence and anti-Austrian behavior over the preceding five years, began to mobilize its forces immediately the reply was received, and declared war on Serbia on July 28. It soon thereafter bombarded Belgrade (which was within reach from Hungarian territory) but was not prepared to invade until August 12. 
It was understood in Russia and elsewhere that Russian mobilization of its army would be more time consuming than mobilization in Germany, Austria, or France. Russian officials in succession ordered a pre-mobilization, a partial mobilization, and a full mobilization, the latter cancelled by the Tsar on July 29 and then re-instated a day later. Austria on July 31 responded with general mobilization, and Germany declared a "state of threatening danger of war," followed by a full mobilization on August 1, on which day France also mobilized. Germany, influenced by Chancellor Bethmann's sense of legal rectitude, declared war on Russia. Germany's war plan (the Schlieffen Plan going back to 1908) entailed first hitting France hard, westward through Belgium away from the heavily fortified French-German border, requiring it to sue for peace early, thus permitting the German troops to be moved eastward to face the slow-response Russians. In a pre-emptive move, Germany invaded Luxembourg on August 2, and requested Belgium to allow its troops to pass through to the French border. When this was (predictably) denied, Germany invaded Belgium on August 3 and declared war on France. This invasion tipped the balance within the neutral-leaning British cabinet toward declaring war on Germany, since Britain had been a guarantor of Belgium's integrity since its creation in 1830, and strategically Britain did not want Germany to dominate the Scheldt River or to be lodged on the coast directly opposite Britain. Foreign minister Grey argued that without strong reaction to this German provocation, Britain's credibility (to use a contemporary term) would be questioned around the world. Moltke had insisted on the invasion of France through Belgium for technical military reasons, driven partly by strategy but even more at that time by the details of logistical planning - "war by timetable," as AJP Taylor later called it -- an action that in 
the words of McMeekin (2013, p.401) was "a political, diplomatic, strategic and moral blunder of the first magnitude."

Who then was responsible for starting the European-wide war among the major powers? Austria wanted war, but only with Serbia. Austria assumed that unambiguous German backing would keep Russia at bay. France and especially Britain were not especially concerned - the assassination and Austria's reaction was just another event in the troublesome Balkans, to be managed (as in the past) with skillful diplomacy. It is also true that in July 1914 the British government was preoccupied once again with the question of Home Rule for Ireland; and France was preoccupied with the sensational trial of Mme. Caillaux for killing an editor for his attacks on her husband, leader of the Radical party and prospective prime minister but for the trial. Caillaux called for a less aggressive foreign policy and President Poincare feared he would reduce the size of the French army.

The Russians knew that their mobilization would provoke a German mobilization and almost certainly lead to a major war. Poincare of France, Russia's strong ally, was from Lorraine and was conspicuously anti-German. He probably did not seek war, and he certainly wanted to avoid starting a war in the knowledge that would alienate Britain, whose support he sought and expected under the right conditions. But he probably welcomed war if it was started elsewhere and if he could count on Russian support, to rectify past wrongs and future threats by Germany. Thus the knowledgeable decision for a European war was by Russia. We need to look more closely at Russian circumstances and Russian objectives. 
Russia

Russia in 1914 was formally an absolute monarchy under a tsar, who in the early $20^{\text {th }}$ century was Nicholas II, a weak personality but the ultimate decision-maker on matters of foreign policy and war and peace. Russia had greatly expanded eastward in the $18^{\text {th }}$ and $19^{\text {th }}$ centuries, and still had territorial aspirations in China and in Korea (challenged by Japan) and in Persia and Afghanistan (challenged by Britain). It also wanted more secure borders in Europe, having its eye on the Carpathian Mountains, west of Austria's East Galicia, having earlier absorbed Finland and much of Poland. Above all, it sought control of access to the Mediterranean and wider oceans from the Black Sea through the Bosporus and Dardanelles, which in practice meant controlling Istanbul. There were spiritual and religious reasons for this objective as well as economic and geo-political ones. Russia saw itself as the "third Rome," the seat and protector of orthodox Christianity since the fall (in 1453) of Constantinople and the Byzantine Empire. Many orthodox Christians were under Ottoman rule, where they were treated (it was argued) as second-class citizens.

Russia had experienced major domestic disturbances, pressures for relief from absolute rule, which led in 1906 to the creation of an elected legislature (Duma), with some legislative powers, but with the Tsar retaining ultimate authority. It had also suffered a crushing defeat, both on land and at sea, by the Japanese in 1904-05, over which country would be dominant in Manchuria and in Korea. Compared with the increasingly industrialized Western Europe and North America, Russia was a relatively backward country. But Russian leaders wanted to catch up, more for power and status than for prosperity for their people. And in the pre-1914 period it was showing some success: Russia's GDP grew at 2.4 percent a year in the period 1870-1913, 
slower than Germany but faster than Britain, and by an impressive six percent a year in 19081913 (Maddison, 2001, p.262; McDonald, p.205). Industrialization was beginning to take hold, largely with strong government initiative and support, including high import tariffs, even higher than those in the United States at the time (see Crisp, Miller). But the economy was still largely self-contained and indeed localized. It was a large country with poor internal transportation. It was exporting grain primarily through the Bosporus, and importing modern equipment from western European countries there and through the Baltic to St. Petersburg. (An indicator of internal transportation difficulties is that it was also importing grain from high-cost Germany into northwestern Russia.) By 1913, Russian officials were feeling confident again, although some were still greatly worried about further internal disturbances.

Russians saw the main obstacles to their territorial ambitions in the west as the Austrian and Ottoman empires, and their most serious potential adversary as Germany, mainly because of its alliance with Austria but also because of its strong commercial interests in the Ottoman empire, as reflected for example in the prospective Berlin to Baghdad railway. It relied on its alliance with France, strongly re-affirmed in the July 1914 summit, to distract and pre-occupy the German army in the event of war, playing skillfully on the strong residual resentment at the reparations and loss of Alsace and Lorraine in 1871, still in living memory of French leaders.

Russians planned an amphibious invasion of European Turkey, near Istanbul, as well as from the Caucasus into eastern Anatolia, along with the occupation of eastern Galicia, while the French tied up the main German forces in the west (McMeekin, 2011). The French in sharp contrast wanted Russia to attack Germany in East Prussia as soon as possible to draw significant German forces away from the western front. France made large loans to Russia in 1906 on the 
condition Russia reach an armistice with Japan, permitting its troops to move west, and again in 1913 on condition Russia improve its railway network, with the objective of mobilizing troops and bringing them into action more quickly. Indeed, capital outflows from both France and Germany (as reflected in Table 2) during the pre-1914 period were often politically motivated, encouraged, and approved (McDonald, McMeekin, 2011).

Russian prospects in 1914 seemed formidable, at least to German and French leaders. It had a large and growing population; it was industrializing successfully; and it had plans to raise the size of its standing winter army (including conscripts) to 2 million by 1917, an army that would be better trained and equipped than that in 1913 and would surpass the German army in size. Above all, as McDonald (2009) has emphasized, Russia had a much stronger fiscal position than either France or Germany, thanks in part to profits from state monopolies such as the railroad and production of vodka. From Germany's perspective, Russia was the rising power. And Poincare worried that in time Russia would become less dependent on France, both strategically and financially. Thus time was not on their side.

Russia had a more immediate concern. Amphibious invasion of Turkey would require naval predominance in the Black Sea, which Russia had in 1913. But the Ottomans had ordered four new Dreadnought-class battleships abroad, two in Britain that were due to be delivered in late 1914 or 1915. Under the Straits Convention of 1841, modified only slightly in the Berlin Treaty of 1878 , no country, including Russia, could move warships through the Straits in peacetime. Thus Russia had to build its own warships in the Black Sea, and battleships of this quality would not be ready until 1917. Delivery of these new warships would provide Turkish naval dominance in the Black Sea in the near future, thus foiling any sea-based attack. 
Russia's interest in a European war was thus very different from that of other countries.

If all went well, Russia could expect to gain, economically as well as in stature, territory, and population, from a successful war. As we saw in Table 1, Russia's economic engagement with other countries was much lower than that of the western European countries. Controlling the Straits would increase Russian influence in the eastern Mediterranean (and possibly threaten the Suez Canal, Britain's key route to India) and make foreign trade from southern Russia more secure. (The Ottomans had closed the Straits to Russian commercial trade briefly during the Balkan wars, but they were re-opened again after international protest.) Russian incentives were thus very different from those of Britain or Germany, about which Angell was writing. (According to Lambert (2012), the much maligned Dardanelles campaign of 1915 was not only to provide strategic diversion from the western front, as is usually said, but even more to permit export of Russian grain, badly needed in Britain, and the transfer of British arms into Russia.)

Unfortunately for Russia, all did not go well. To be sure, First Lord of the Admiralty Winston Churchill diverted the two Ottoman battleships into the British navy, thus preventing their delivery to Istanbul. But early in the war two German warships, escaping British pursuit in the Mediterranean, requested and were granted refuge in Ottoman waters. The larger of the two, the Goeben, while not a Dreadnought, outclassed all the Russian warships in the Black Sea. This of course compromised Ottoman neutrality in the war. So the Germans "sold" the two ships to Turkey, along with their German crews and commanders, who were commissioned in the Ottoman navy (with permission from Berlin). This unexpected development effectively 
made a Russian amphibious attack prohibitive. As Clausewitz or someone said, once a war starts all pre-war plans become obsolete.

Russia's main military thrust was in East Galicia, where its armies initially gained the upper hand (Austria had moved many troops south to invade Serbia, wrongly guessing that Russia would not attack). But to support its French allies, Russia also invaded East Prussia with two army corps. They outnumbered the defending Germans, but due to poor communication and coordination between the Russian armies (and some antagonism between the two Russian generals), the Germans defeated first one corps and then the other in the battle of Tannenberg - another unexpected event, both by the Germans, who had been prepared to retreat to a more defensible line, and by the Russians.

\section{Personalities and Public Opinion}

We tend in normal discourse to personify nations and governments. But people, not countries, make decisions. Foreign and military policy in all the great powers in 1913 were made by relatively few people, albeit influenced by press commentary in all countries, even in Russia. And the press often reflected the views of organized pressure groups and of public sentiment more generally. In Russia, Tsar Nicholas II was the ultimate decision-maker on these issues, but he was strongly influenced by foreign affairs minister Sazonov and minister of war (and general) Sukhomlinov, as well as by other members of the cabinet.

In France, Raymond Poincare was the dominant figure, even though as president he had few formal powers; Prime Minister Viviani was only a placeholder until the trial of Mme. Caillaux concluded, and was inexperienced in foreign affairs. Joffre commanded the army. 
In Germany, the erratic Kaiser Wilhelm II, often belligerent in words but shrinking from actual combat, was the highest authority, with Bethmann-Holweg as Chancellor and Moltke as chief of the general staff. In Austria, Franz Josef was emperor, advised by Berchtold on foreign policy with Conrad as army chief of staff. Asquith was Prime Minister of Britain with Grey as influential foreign minister, but the Cabinet participated in most key decisions.

The top military figures in Russia, Austria, and Germany had direct access to their emperors, without necessarily going through the civilian ministers. And in all three cases they not only had responsibility of preparing for war, which was natural, but in each case they advocated war: Conrad with respect to Serbia, Moltke with respect to Russia (necessarily thereby taking on France), Sukhomlinov with respect to Austria and Istanbul. Prime ministers and foreign ministers were generally more cautious, but were gradually brought around, whether by external events or internal argument.

There were serious anti-war voices in all countries, and in all governments. These voices were eventually either sidelined, e.g. Kokovstev in Russia, or overwhelmed by events, e.g. by the assassination the cautious Franz Ferdinand in the case of Berchtold, or by Germany's attack on Belgium in the case of Britain.

Press commentary in 1913 was widely divergent, from chauvinistic and even xenophobic to cautionary and internationalist. Publics however were easily worked up by threats or actions by potentially hostile foreigners, and once the war started the press and public opinion, with rare exceptions, became nationalistic and hostile to the enemies. Partial exceptions were 
polyglot Austria and relatively uneducated Russia, where conscription was universal but unpopular.

We now know how the war came out. It was much longer and much more costly in lives and resources than anyone had imagined in 1914. Four empires disappeared, and the two leading European democracies were greatly weakened. Russia experienced a revolution (with German help in conveying Lenin from Switzerland to Finland) that introduced a communist dictatorship for the next seven decades. If leaders had forecast the actual costs, they undoubtedly would have worked much harder to avoid war, even the generals. But each government thought its approach not only had a chance of working in the country's perceived interests, but that it would work. Moltke was perhaps the most pessimistic, but he was also pessimistic about the alternatives and on balance opted for preventive war.

Lessons?

It is doubtful that one can learn lessons from history. And the lessons learned from history may be the wrong lessons, as when Germany in 1914 thought it could drive France quickly to plead for an armistice, as it did in 1871, or that winners of wars can gain in material terms, as they often had in the past.

But history can stimulate the imagination. It is certainly possible, as Angell warned in 1910, and as actually occurred in 1914-18, that even the winner of a future war may end up much worse off than it was before the war, and, more conjecturally, than it would have been without the war. 
Economic interdependence is much higher in 2013 than it was in 1913 for most countries, including China and the United States (see Tables 1 and 2). War would be extremely costly for both, beyond the direct budgetary costs. That it would be more costly to China than to the USA, because of the likely international isolation of China and quicker recovery of the United States, is small consolation. The governments of both countries recognize that. The lesson of this paper, if there is one, is to beware of third countries. Do not focus only on the leading protagonists alone. Every society has its collective hang-ups and vulnerabilities; skillful outside parties can exploit national sentiments to engender conflicts that are objectively irrational in material terms.

Who might those third countries be in the contemporary context? North Korea, Taiwan, and Iran come immediately to mind. But it is also worthwhile to keep an eye on others, e.g. perhaps Japan and, yes, even Russia again, which might calculate that a serious conflict between China and the United States would enhance its status in the world - something that some Russians always seem to be seeking, without having to earn it.

\section{References}

Angell, Norman, The Great Illusion: A Study of the Relation of the Military Power in Nations to their Economic and Social Advantage, London: William Heinemann, 1910.

Bairoch, P., “European Trade Policy, 1815-1914," in Cambridge Economic History of Europe, vol. 8, Cambridge University Press, 1989. 
Bordo, Michael D., Alan M. Taylor, and Jeffrey G. Williamson, eds., Globalization in Historical Perspective, Chicago: University of Chicago Press, 2003.

Chiswick, Barry R., and Timothy J. Hatton, "International Migration and the Integration of Labor Markets," in Bordo et al., 2003.

Clark, Christopher, The Sleepwalkers: How Europe Went to War in 1914, New York: HarperCollins, 2013.

Cooper, Richard N., "Global Imbalances: Globalization, Demography, and Sustainability," Journal of Economic Perspectives, 22 (summer 2008)3, pp.93-112.

Cowley, Robert, "The What Ifs of 1914: the World War that Should Never Have Been," in Cowley, ed., What If? Military Historians Imagine What Might Have Been, New York: Putnam, 1999.

Crisp, Olga, Studies in the Russian Economy Before 1914, Macmillan, 1976.

Ferguson, Niall, The Pity of War, New York: Basic Books, 1999.

Flandreau, Marc, and Frederic Zumer, The Making of Global Finance, 1880-1913, Paris: OECD, 2004.

Lambert, Nicholas A., Planning Armageddon: British Economic Warfare and the First World War, Cambridge, MA: Harvard University Press, 2012.

Langer, William L., ed., An Encyclopedia of World History, $4^{\text {th }}$ ed., Boston: Houghton Mifflin, 1968. 
Maddison, Angus, The World Economy: A Millennial Perspective, Paris: OECD, 2001 [available at www.ggdc.net/maddison/]

McDonald, Patrick, The Invisible Hand of Peace: Capitalism, The War Machine, and International Relations Theory, New York: Cambridge University Press, 2009.

McMeekin, Sean, July 1914, New York: Basic Books, 2013.

McMeekin, Sean, The Russian Origins of the First World War, Cambridge: Harvard University Press, 2011.

Miller, Margaret S., The Economic Development of Russia, 1905-1914, London: King\&Son, 1926.

Mitchell, Brian R., International Historical Statistics, London: Palgrave Macmillan, 2003.

Obstfeld, Maurice, and Alan M. Taylor, "Globalization and Capital Markets," in Bordo et al., 2003.

Findlay, Ronald, and Kevin H. O’Rourke, “Commodity Market Integration, 1500-2000," in Bordo et al., 2003.

Taylor, A.J.P. War by Timetable: How the First World War Began, London: Macdonald \& Co, 1969.

Turner, L.C.F., Origins of the First World War, New York: WW Norton, 1970. 
Tables and Figures

Table 1 - Merchandise Exports (Percent of GDP)

\begin{tabular}{lrrrr} 
& 1870 & 1913 & 1973 & 1998 \\
\cline { 2 - 5 } UK & 12.2 & 17.5 & 14.0 & 25.0 \\
France & 4.9 & 7.8 & 15.2 & 28.7 \\
Germany & 9.5 & 16.1 & 23.8 & 38.9 \\
Spain & 3.8 & 8.1 & 5.0 & 23.5 \\
Russia & na & 2.9 & 3.8 & 10.6 \\
USA & 2.5 & 3.7 & 4.9 & 10.1 \\
India & 2.6 & 4.6 & 2.0 & 2.4 \\
China & 0.7 & 1.7 & 1.5 & 4.9 \\
Japan & 0.2 & 2.4 & 7.7 & 13.4 \\
World & 4.6 & 7.9 & 10.5 & 17.2
\end{tabular}

Source: Findlay and O'Rourke (2003), p.41.

Table 2 - Foreign Assets (Percent of GDP)

\begin{tabular}{lcc} 
& 1914 & 2005 \\
\cline { 2 - 3 } UK & 92 & 244 \\
France & 67 & 174 \\
Germany & 26 & 99 \\
USA & 8 & 90 \\
Japan & neg.
\end{tabular}

Sources: 1914, calculated from Maddison (2001); 2005, Cooper (2008). 